\title{
ДОННЫЕ И БЕРЕГОВЫЕ ОТЛОЖЕНИЯ ТЁПЛОГО ОЗЕРА (ЛЯММИЯРВ)
}

Псковско-Чудское озеро состоит из трех более или менее самостоятельных частей: северной, называемой Чудским озером (по-эстонски Пейпси), южной, называемой Псковским (по-эстонски Пихква) и соединяющего их Тёплого озера (по-эстонски Ляммиярв). С геологической точки зрения последнее является самым сложным и интересным, что и послужило основой для его тщательного дополнительного изучения после выхода сводной работы по донным осадкам Псковско-Чудского озера (Донные ..., 1981). Несмотря на ограниченную площадь $\left(236\right.$ км²) $^{2}$ и объем воды $\left(0,603 \mathrm{~km}^{3}\right)$ именно здесь находятся нагбольшие глубины Псковско-Чудского озера, достигающие своего макспмума - 15,3 м межлу Мехикоорма и Пнево. Если Чудское и Псковское озера имеют довольно ровный рельеф дна и выровненную береговую линию, то рельеф дна Тёплого озера отличается большой перемежаемостью. Это обусловлено наличием реликтов бывшей гидрографической сети - древней долины р. Великой и ее притоков. Она неодинаково заполнена донными отложениями, что обусловливает частые и большие изменеиня в глубинах озера даже на близлежащих vчастках (Раукас. Ряхни, 1981).

Гидрологические условия относительно длинного $(28,5$ км) и узкого (1,8-12.5 км) Тёплого озера являются также сложными. Ввиду впадения в Псковское и Тёплое озера полноводных рек Великой, Пиузы, Выханду, Желчи и др. здесь наблюдаются интенсивные стоковые течения, обvсловливающие абразию дна и берега. Зарегистрированные максимальные скорости течения в Тёплом озере доходят до $51 \mathrm{~cm} / \mathrm{c}$ (Kallejärv, 1973), что больше чем достаточно для интенсивной абразии и значительного перемещения наносов. Водообмен с Чудским озером спстоится по двvм проливам. называемыми «эстонскими» (западнее о-ва Пийриссаар) и «русскими воротами» (восточнее острова). Ориентировочно измеренные расходы воды через «эстонские впрота» колеблются от 15 до $250 \mathrm{~m}^{3} / \mathrm{c}$, через «русские» - от 159 до $1067 \mathrm{~m}^{3} / \mathrm{c}$, т. е. основной водообмен происходит через последние (Гидрометеорологический .... 1983).

Высота волн при скорости ветра $20 \mathrm{~m} / c$ достигает 0,8-1,0 м. при ветре cn скоростью $10 \mathrm{~m} / \mathrm{c}-0,3-0.6 \mathrm{~m}$ (Гидрометеорологический ..., 1982). Пропклалают западные и юго-запалные ретры сn скоростью 4$5 \mathrm{~m} / \mathrm{c}$, но бывают и vраганные, достигаюшие $24 \mathrm{~m} / \mathrm{c}$. Ледостав в озере vстанавливается р конше ноябпя-начале пекабпя и держится, по данным за перипд 1943-1975 гг.. в среднем 128 суток. Наибольшая толщина льла $(50-60$ см) обычно наблюдается в марте или начале апреля (Гилрометеорологический .... 1983).

Коренные поролы в районе озера представлены среднедевонскими красноцветными или светлыми алевролитами и песчаниками (с прослоями глин) буртниекского и швентойского горизонтов. Поверхность коренных попод сильно расчленена погребенными или полупогребенными долинами (Ряхни. Таваст, 1981). Одна из них вћлизи пос. Мехикоорма глубиной около 75 м (дно долины располагается на 45 м ниже уровня моря) и шириной около 1 км протягивается в юго-восточном направле- 
нии вдоль озера. По гравиметрическим данным ее глубина вблизи дер. Березовец составляет 70 м и ширина 0,9 км (Tavast, 1978). На этом месте (примерно в современной долине р. Выханду) в нее впадает другая древняя долина почти такой же глубины. В основную меридиональную долюну впадают притоки с запада и востока также близ Мехикоорма.

В современном рельефе дна озера выделяется ряд блюдцеобразных впадин. Самая глубокая из них (до 15,3 м) между Мехикоорма и Пнево длиной порядка 8 км и шириной около 350 м называется Мехикоормаской. В северной части озера наблюдается ряд отмелей и относительно глубоких (более 4 м) впадин. Наибольшие глубины (5,9 м) установлены между мысом Ухтина и о-вом Пийриссаар $(6,0$ м) и в мелкой блюдцеобразной впадине к югу от о-ва Вороний $(5,9$ м). В южной половине озера выделяется Салуская ложбина длиной около 11 км, шириной порядка 1 км и глубиной до 9,6 м. Имеется также ряд более мелких ям с относительной глубиной 1,5-2 м (напр., близ Райгла) и подводных банок (напр., Салуская) с относительной высотой 2-3 м. Западный берег озера более выровнен, чем восточный и глубины здесь побольше (Раукас, Ряхни, 1981).

Мощность четвертичных отложений в окружающей озеро впадине составляет обычно 5-10 м, но достигает в древней долине у дер. Линте вблизи пос. Ряпина, по данным А. Верте, 146+ м. Нижне- и среднеплейстоценовые отложения во впадине уверенно не установлены. Среди верхнеплейстоценовых отложений преобладает морена, которая является исходным для береговых и донных отложений озера. Морена характернзуется красно-бурым цветом и разным соотношением местного и эрратического материала. Обычно преобладает материал кристаллических пород (порядка $80-90 \%$ ), среди которых наблюдается много обломков рапакиви $(20-30 \%)$. Морена содержит мало грубой фракции, галечник не превышает $10 \%$, валуны редки (Раукас, 1978).

В легкой мелкопесчаной фракции морены преобладают кварц (порядка $90 \%$ ) и полевые шпаты (до 15\%). Содержание карбонатов не превышает $5 \%$. Выход тяжелой подфракции в большинстве случаев составляет $0,6-1,0 \%$, основными минералами являются гранат, амфиболы и магнетит-ильменит, содержание которых колеблется обычно в пределах 20-30\%. Содержание гематита и гидроокислов железа около $10 \%$, а циркона примерно $2-4 \%$.

Ввиду того, что воды озера за голоценовое время интенсивно наступали к югу (начиная с бореального климатического периода уровень воды в Вярскаской бухте Псковского озера повысился почти на 10 м) (Пиррус, Тасса, 1981), они приспосабливались в основном к плейстощеповому рельефу. В зависимости от исходного рельефа здесь наблюдаются разные типы берегов (рис. 1). Абразионные расположены отрезками на восточном берегу севернее Подборовье и близ Подолеще, на западном берегу у Райгла и Мехикоорма. Типичные аккумулятивные берега отсутствуют. Аккумуляция мелкозернистых наносов происходит только в условиях весеннего половодья и во время штормов. На значительных территориях берег заросший или зарастающий. Встречаются как уступистые (моренные, песчаные, торфяные), так и низменные (моренные, песчаные, торфяные, илистые) берега. Уступистые моренные берега прослеживаются, например, у Пнево и Йэпера. Высота уступа составляет 1,5-2 м, иногда морена покрыта тонким слоем песка (Йэпера). На подводном склоне и на подножье уступа наблюдается множество валунов. Пляж обычно задернованный и уступ абрадируется только в условиях весеннего половодья. В некоторых местах на подводном склоне растет тростник. Ширина тростниковой зоны достигает 100 м. Уступистый песчаный берег распространен местами у Райгла, а уступистые 
Рис. 1. Типы берегов Тёплого озера. 1 задернованный берег; 2 - незадернованный моренный берег; 3 - незадернованный песчаный берег; 4 - незадернованный галечный берег; 5 - береговье валы и уступы; 6 -абразионный берег в торфе: 7 - переотложенный торф; обнаженные или покрытые маломощным слоем донных осадков отложения на дне озера; 8 морена; 9 - ленточные глины; 10 - торф.

торфяные берега - на восточном берегу южнее Подолеще и устья р. Ровья. Высота уступов доходит до $1 \mathrm{M}$.

Низменные берега занимают более обширную площадь, уступистые - меньшую (обычно они сильно задернованы). Характерный низменный моренный берег прослеживается у Лааксааре, илистый между Островом и Пнево, песчаный - близ Таммисту, а торфяной - местами от устья р. Ровья до Яблонки. Во время половодья и штормов они затапливаются.

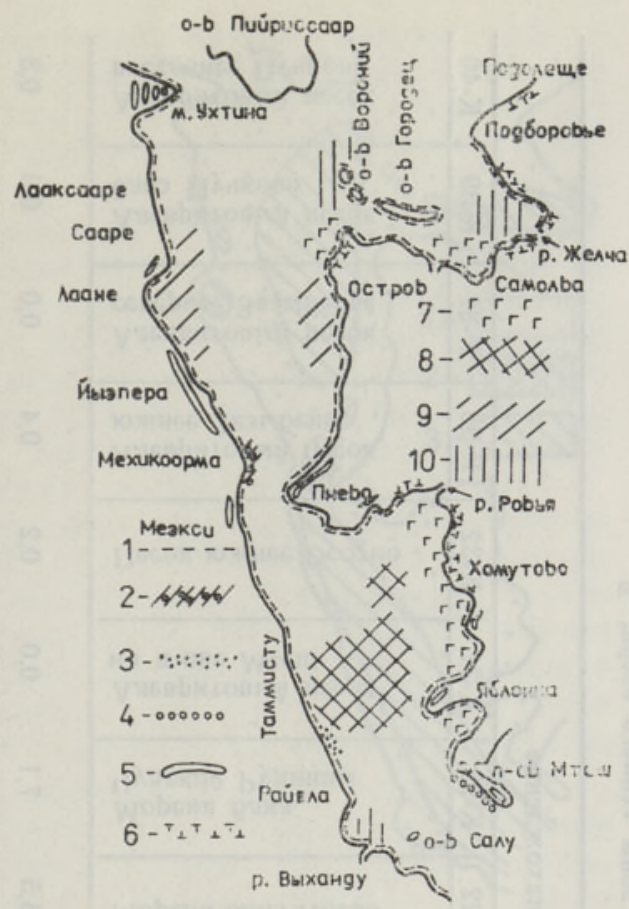

Гранулометрический состав донных отложений предопределяется особенностями рельефа дна, составом исходных отложений и гідрологическим режимом озера (таблица, рис. 2). Ввиду расчлененного рельефа мощности и структурные типы отложений здесь значительно изменчивсе, нежели г Псковском и Чудском озерах. Мощность отложений местами превышает 10 м и в общем увеличивается в сторону осевой части озера (Раукас, Ряхни, 1981). В ряде мест до!ные отложения практически отсутствуют и на дне озера обнажаются морепа (близ Хомутсво и п-ова Мтеш), ленточные глины (близ Лаане и Острова) или девонские песчаники (у о-ва Вороний). На довольно больших площадях озерного дна обнажается торф (например, севернее Самолва и в устьевой части р. Выханду) или он покрыт лишь маломощным (20-30 см) слоем донных осадков. Близ устья р. Выханду мощность торфа превышает 3 м.

Донные осадки Тёплого озера богаты органикой. Содержание последней доходит до $83,3 \%$ (Раукас, 1981). В песках и песчаных алевритах органического вещества обычно меньше $5 \%$, за исключением случаев содержания в них кусков торфа. В пелитовых и пелитистых алевритах (илах) содержание тонкораспыленного органического вещества обычно колеблется в пределах $10-30 \%$, что в значительной мере затрудняет определение гранулометрического состава осадков.

Без предварительного удаления органического составляющего в срединной (осевой) части озера наиболее характерными донными отложениями являются пелитовые алевриты. К периферийным частям озера чаще всего приурочены алевритовые, алевритистые, пелитисто-алевритовые и алевритисто-пелитовые пески, но встречаются также мелкозернистые пески (Раукас, Ряхни, 1981).

После удаления органики методом сжигания картина существенно меняется (рис. 3). По подсчетам В. Калма (Kalm, 1976), среди 63 более или менее равномерно расположенных образцов донных отложений преобладают пески (37 образцов или 59\%) и алевриты (23 образца или 


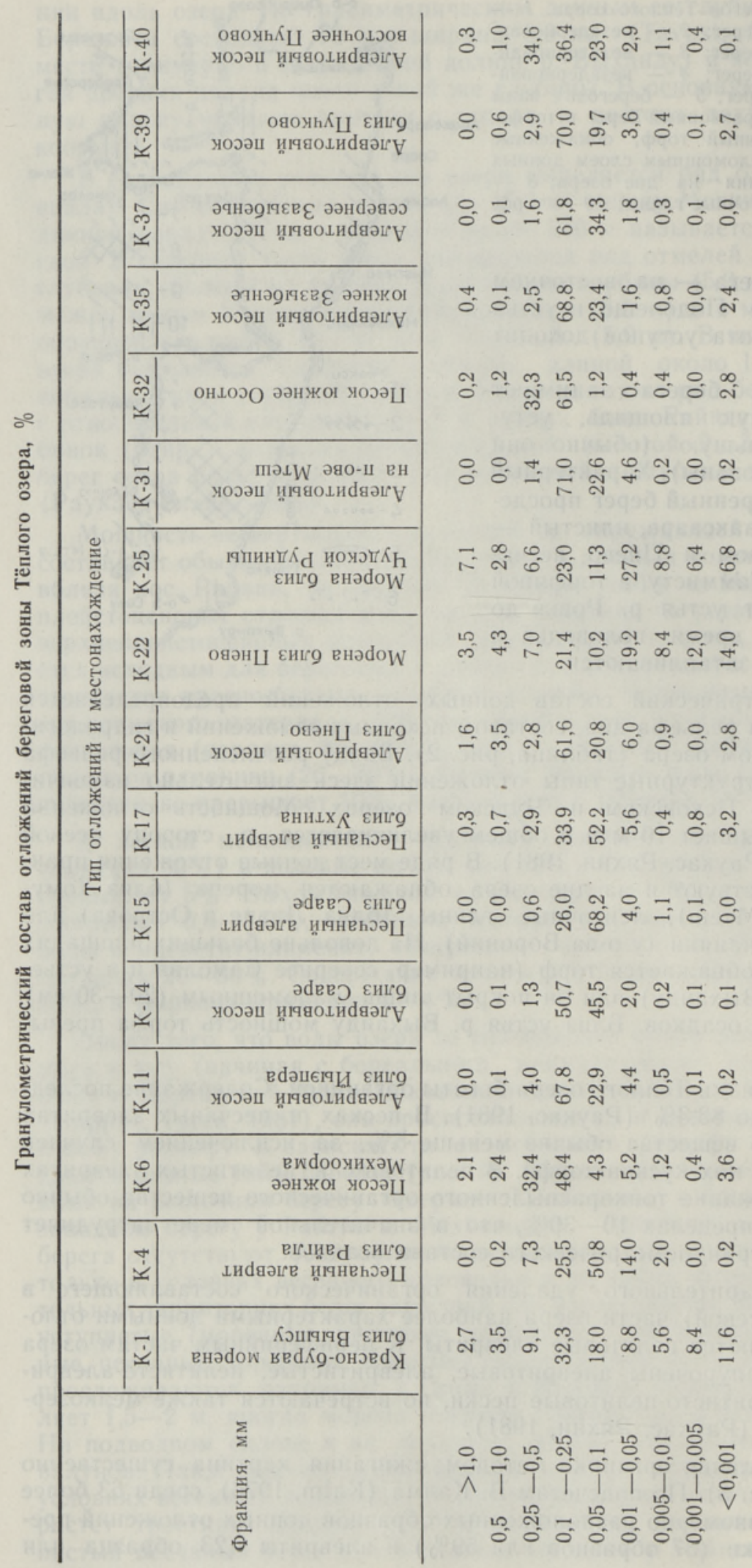




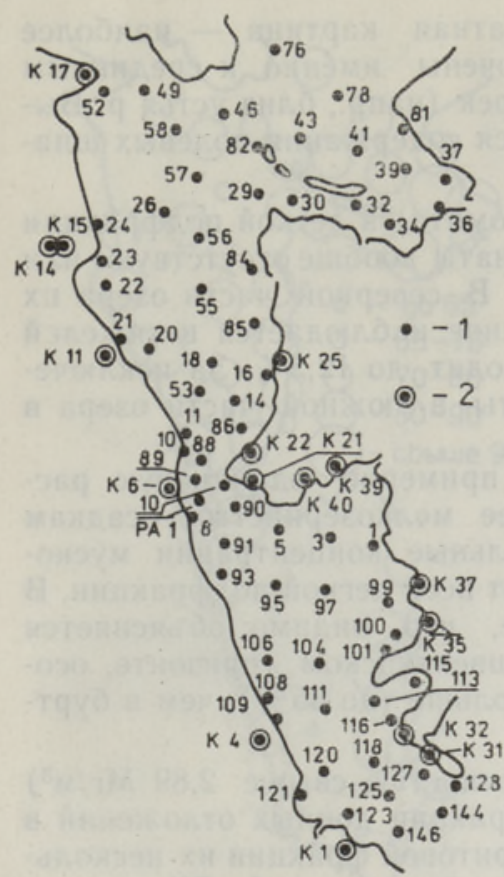

Рис. 2. Схема отбора нзученных образцов: 1 - из донных осадков; 2 - из отложений берегоной зоны.

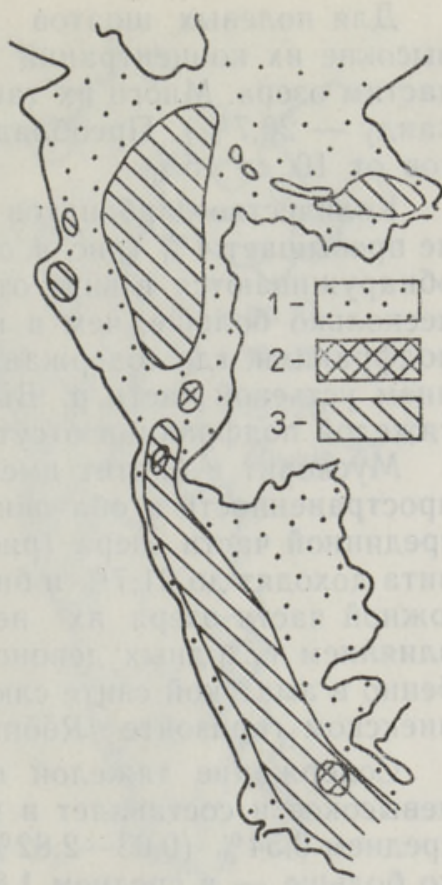

Рис. 3. Принципиальная схема распределения донных осадков Тёплого озера после удаления органического составляющего: 1 - пески, 2 - миктиты; 3 - алевриты.

$36 \%$ ), количество миктитов (Raukas, 1964) небольшое (3 образца или $5 \%)$. Среди песков, кроме чистых разновидностей $(19,1 \%)$, встречались алевритистые $(14,3 \%)$ и алевритовые $(11,1 \%)$, пелитисто-алевритовые $(3,2 \%)$ и пелитисто-алевритистые $(11,1 \%)$. Среди алевритовых отложений преобладали пелитисто-песчанистые $(17,5 \%)$ и пелитисто-песчаные $(12,7 \%)$. Песчанистые пелитоалевриты составляли $3,2 \%$, а чистые алевриты вообще не обнаружены.

Кроме древней долины р. Великой алевриты широко распространены в мелководном заливе Самолва (рис. 3). Тонкозернистые осадки сюда, видимо, приносились рекой Желча. Течения в этой части озера слабые и вынос осадочного материала практически отсутствует. Реже встречаются алевриты близ западного берега (близ Лаане и Сааре). Интересно отметить, что в пределах древней долины, примерно в двух километрах к северу от Мехикоорма распространение алевритов прерывается (Kalm, 1976), что, видимо, объясняется донными течениями северного направления (Филатова, 1972). На этом месте в долине находится крутая седловина, в которой, благодаря течениям, алевритовый материал не аккумулируется.

Минеральный состав песчано-алевритовых фракций Тёплого озера характеризуется большой изменчивостью. Преобладающими минералами, как и в исходных породах, являются кварц и полевые шпаты, составляющие в большинстве случаев более $95 \%$ от проанализированных фракций (рис. 4, a, б). Содержание кварца в пределах $80-90 \%$ является обычным, 92-93\% - максимальным (рис. 4,a). Наименьшие содержания (64-78\%) свойственны тонкозернистым осадкам в срединной части озера (образцы 46, $57,95,111,118$ и др.). 
Для полевых шпатов характерна обратная картина - наиєолсе высокие их концентрации $(25,2 \%)$ приурочены именно к срединным частям озера. Много их также близ устьев рек (напр., близ устья р. Выханду $-20,7 \%$ ). Преобладающими являются содержания полевых шпатов от 10 до $15 \%$.

Количество карбонатов (кальцита и доломита) в легкой подфракции не превышает 4\% (рис. 4, в). Обычно карбонаты вообще отсутствуют или обнаруживаются в виде отдельных зерен. В северной части озера их несколько больше, чем в южной. Аналогичное наблюдается в тяжелсй подфракции, где содержание доломита доходит до $12,2 \%$. За исключением устьевой части р. Выханду, карбонаты в южной части озера в тяжелой подфракции отсутствуют.

Мусковит и биотит имеют среди слюд примерно одинаковую распространенность и оба они тяготеют к более мелкозернистым осадкам срединной части озера (рис. 4,2 ). Максимальные концентрации мусковита доходят до $21,7 \%$ и биотита до $40,5 \%$ от всей легкой подфракции. В южной части озера их несколько больше, что, видимо, объясняется влиянием исходных девонских пород. В швентойском горизонте, особенно в аматской свите слюд значительно больше (до $35 \%$ ), чем в буртниекском горизонте (Rõõmusoks, 1983).

Содержание тяжелой подфракции (плотностью свыше 2,89 Mr/m²) невысокое и составляет в мелкопесчаной фракции донных отложений в среднем $0,54 \%(0,03-2,82 \%)$, в крупноалевритовой фракции их несколько больше - в среднем $1,86 \%$, в отдельных образцах $-6-7 \%$.

Мелкопесчаная, крупноалевритовая и мелкоалевритовая фракции по качественному составу отличаются мало, но обнаруживаются общеизвестные закономерности в количественном содержании минералов. Так в сторону мелких фракций четко возрастает количество циркона, монацита, рутила, брукита, анатаза и ряда других акцессорных минералов, которые тяготеют также к мелким фракциям исходных девонских песчаников и алевролитов (Вийдинг, 1968).

Преобладающими среди тяжелых минералов мелкопесчаной фракции донных осадков Тёплого озера являются магнетит-ильменит, амфиболы и гранат. Ведvщее место занимают магнетит и ильменит (до 50\%, наиболее часто $20-30 \%$ ). Их максимальные концентрации приурочены к прибрежным районам южной части озера, минимальные (местами менеє $5 \%)$ - к срединным частям, где преобладают тонкозернистые осадки. Особенно мало их в устьевой части р. Выханду и к югу от о-ва Пийриссаар (рис. $5, a)$.

Лейкоксен (обычно 1,5-3,5\%, максимально до $8 \%$ ), апатит (до $4 \%$, макс. $8,4 \%)$ и гранаты $(15-30 \%$, макс. до $48 \%$ ) явно приурочены к северной части озера, что объясняется влиянием исходных девонских пород и морен (Вийдинг, 1968; Раукас, 1978) (рис. 5, б, в, г). Влиянием исходных пород хорошо объясняется также увеличение содержания циркона $(3-10 \%$, макс. до $15,4 \%)$ в южной части озера. Особенно выделяются районы близ Мехикоорма-Пнево и между Райгла-Зазыбенье (рис. $6, a)$. Возрастание концентрации циркона и других тяжелых минералов, таких как ильменит-магнетит, турмалин, гранат и др. в районе Мехикоорма-Пнево объясняется, видимо, гидрологическими условиями бассейна, что привело к усиленному промыванию осадков и к концентрации тяжелых минералов.

Самые высокие концентрации турмалина обнаружены в донных осадках южнее о-ва Пийриссаар (до 7,0\%) и в районе Мехикоорма-Пнево, высокие - в южной части озера близ Райгла и Осотно (рис. $6, б)$.

В содержании амфиболов $(10-30 \%$, макс. до $46,1 \%)$ и пироксенов четкой закономерности не обнаруживается (рис. $6,8,2$ ). В содержаниях ромбических $(0,4-1,6 \%$, макс. $4,5 \%)$ и моноклинных пироксенов (1- 


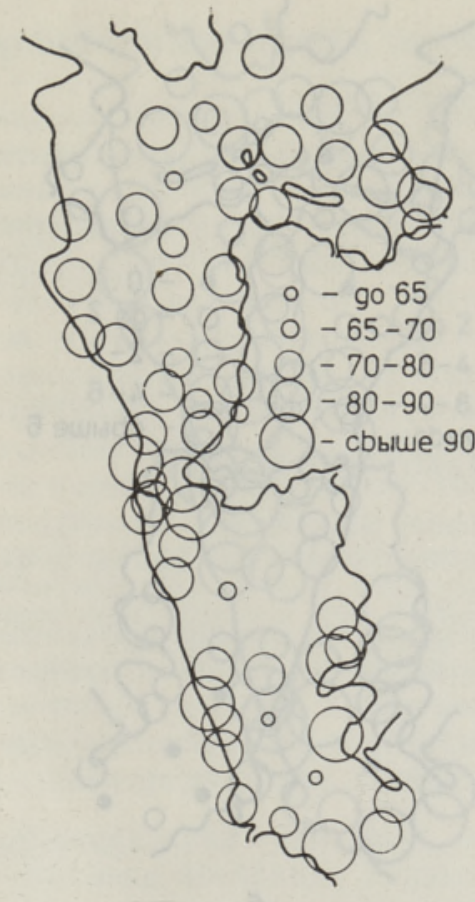

a

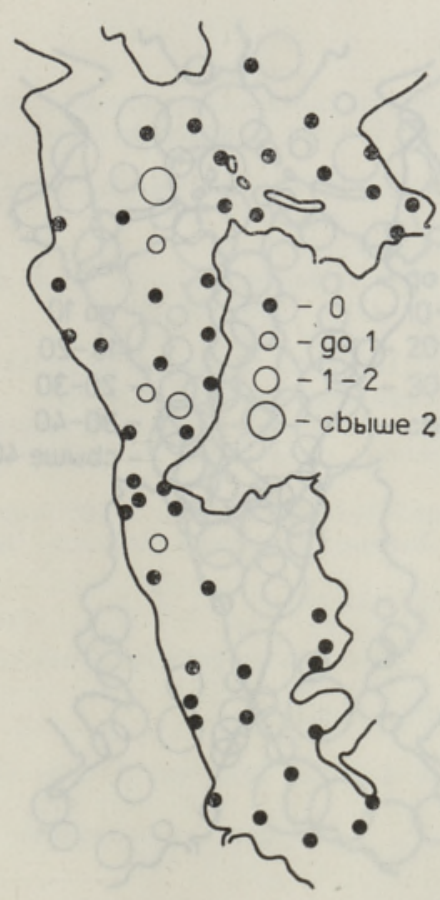

B

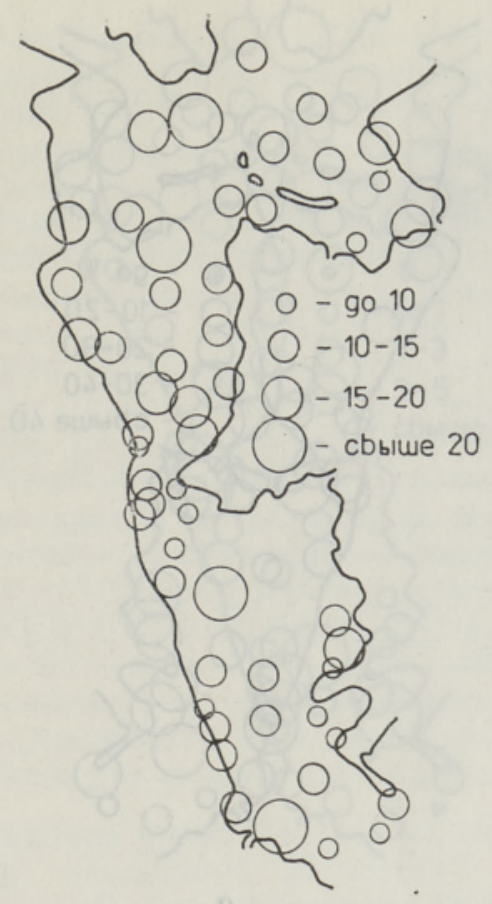

б

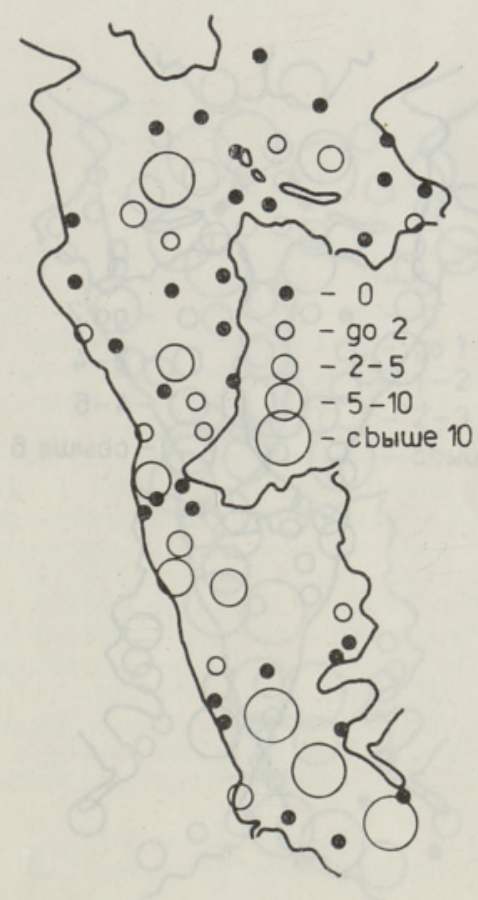

2

Рис. 4. Содержание наиболее характерных минералов мелкопесчаной легкой (менее $\left.2,89 \mathrm{Mr} / \mathrm{m}^{3}\right)$ подфракции в донных отложениях Тёплого озера, \%: $a-$ кварц; 6 - поле вые шпаты; в- карбонаты (кальцит и доломит); $2-$ слюды (мусковит и биотит). 


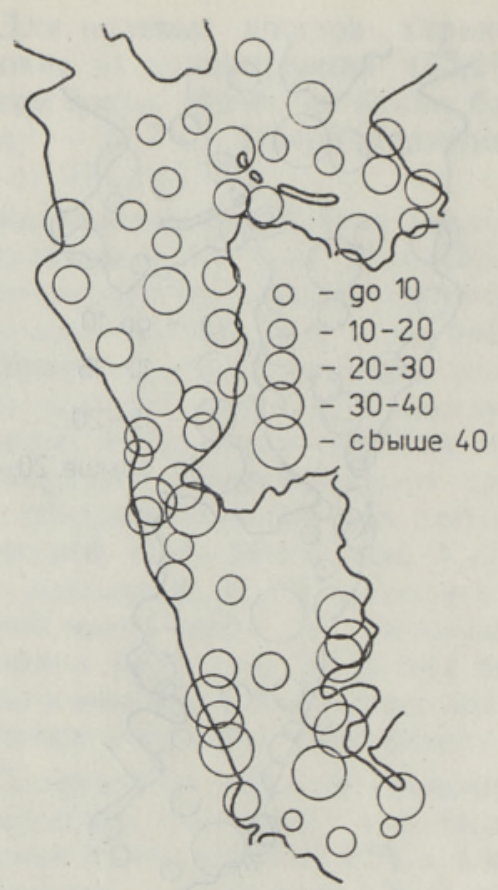

a

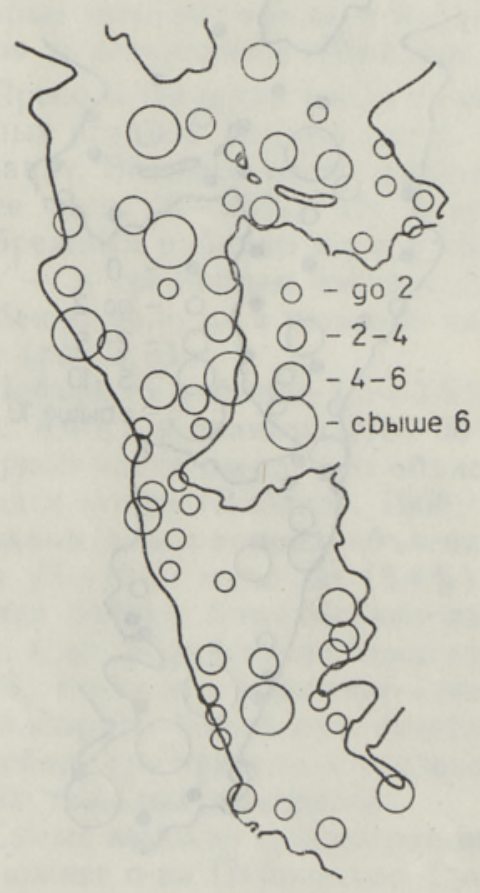

B

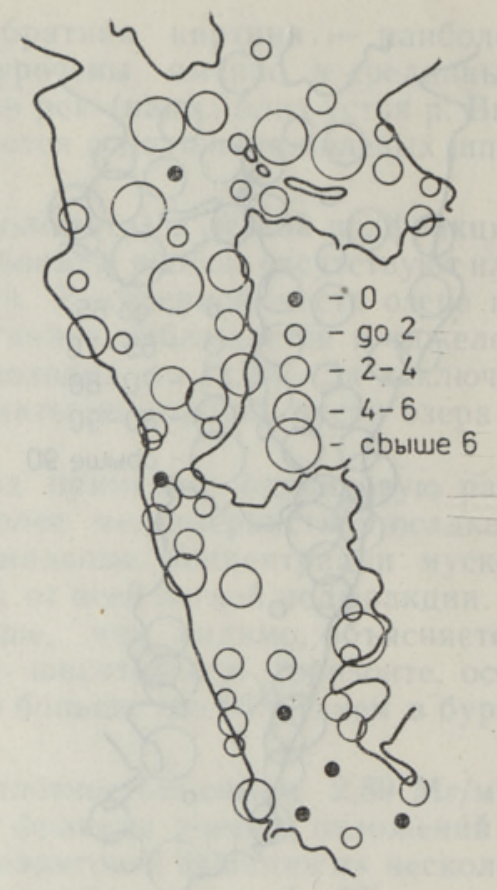

6

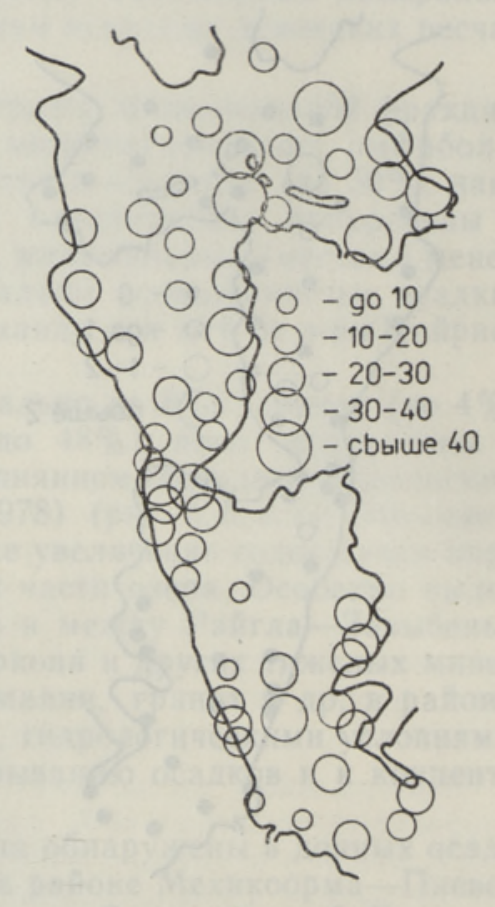

2

Рис. 5. Содержание характерных минералов мелкопесчаной тяжелой (более $2,89 \mathrm{Mr} / \mathrm{m}^{3}$ ) подфракции в донных отложениях Тёплого озера, \%: $a-$ магнетит-ильменит; $6-$ лейкоксен; в- апатит; 2 - гранаты. 


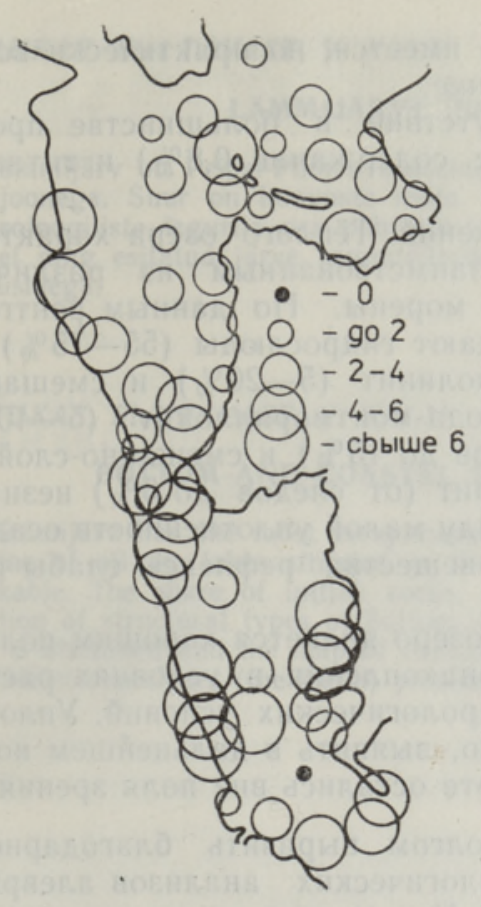

a

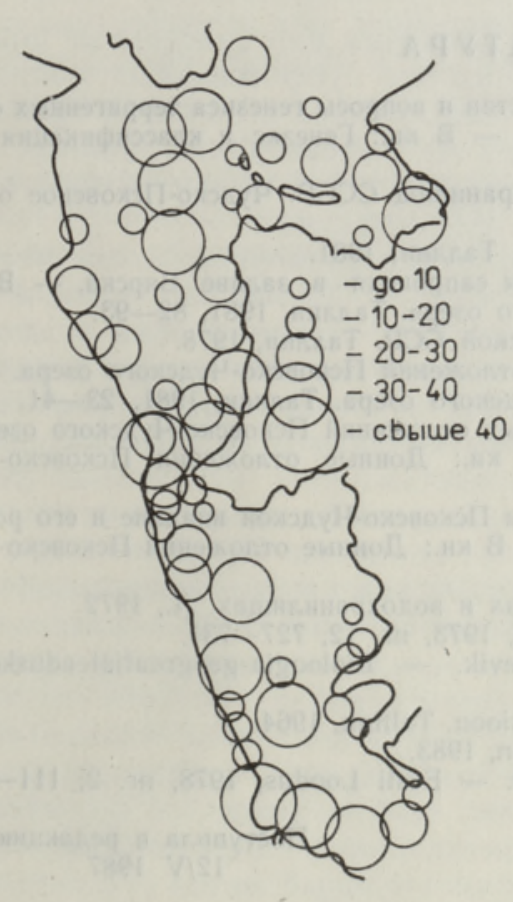

B

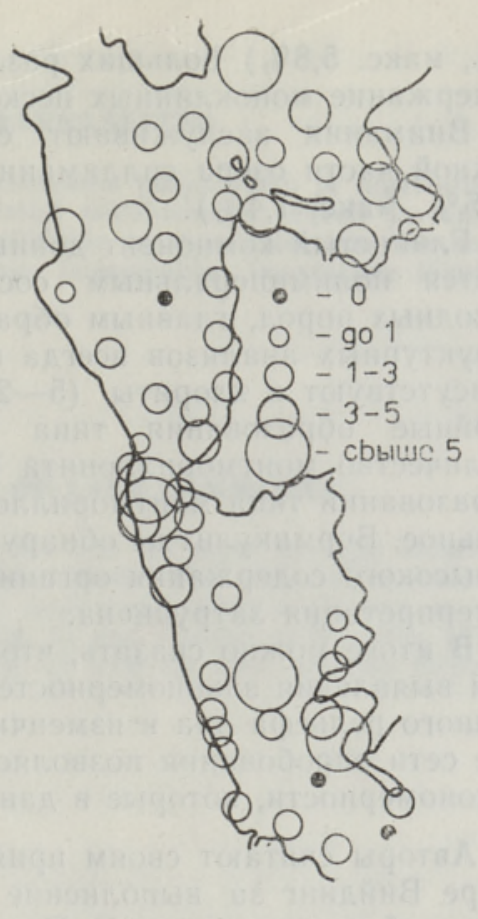

б

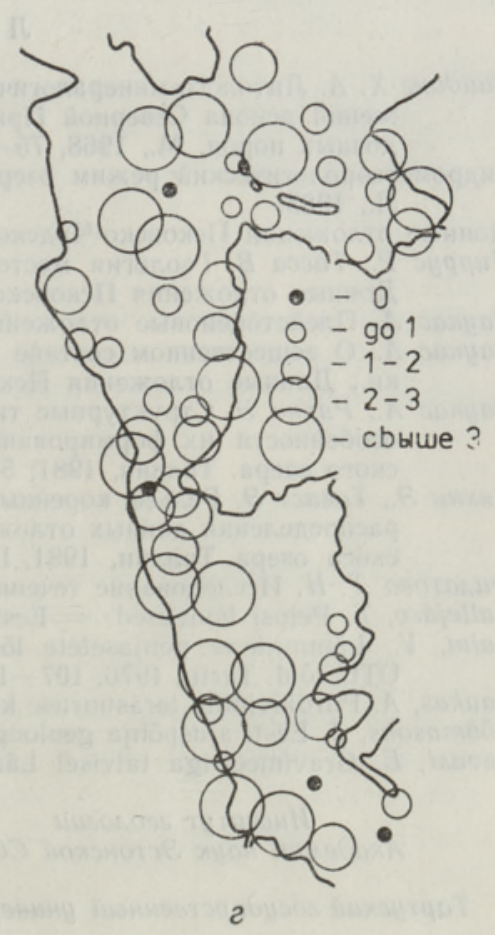

Рис. 6. Содержание характерных минералов мелкопесчаной тяжелой (более $2,89 \mathrm{Mr} / \mathrm{m}^{3}$ ) подфракции в донных отложениях Тёплого озера, \%: $a-$ циркон; 6 - турмалин; $8-$ амфиболы; 2 - пироксены. 
$3 \%$, макс. $5,8 \%$ ) больших различий не имеется, но практически всюду содержание моноклинных несколько выше.

Внимания заслуживают еще отсутствие в большинстве пробах южной части озера силлиманита (макс. содержание $0,8 \%$ ) и титанита $(0,5 \%$, макс. $1,4 \%)$.

Глинистый компонент донных отложений Тёплого озера характеризуется полиминеральным составом, заимствованным из различных исходных пород, главным образом из морены. По данным рентгеноструктурных анализов всегда преобладают гидрослюды $(55-75 \%)$, но присутствуют и хлориты $(5-20 \%)$, каолинит $(5-20 \%)$ и смешаннослойные образования типа гидрослюда-монтмориллонит $(5-40 \%)$. Количество монтмориллонита (от следов до 15\%) и смешанно-слойных образований типа монтмориллонит-хлорит (от следов до $5 \%$ ) незначительное. Вермикулит не обнаружен. Ввиду малой уплотненности осадков и высокого содержания органического вещества рефлексы слабы и их интерпретация затруднена.

В итоге можно сказать, что Тёплое озеро является хорошим полигоном выявления закономерностей осадконакопления в условиях расчлененного рельефа дна и изменчивых гидрологических условий. Уплотнение сети опробования позволяет, видимо, выявить в дальнейшем новые закономерности, которые в данной работе остались вне поля зрения.

Авторы считают своим приятным долгом выразить благодарность Маре Вийдинг за выполнение минералогических анализов алевритопесчаной размерности и Э. Пиррусу и К. Утсалу за рентгеноструктурные анализы пелитовых фракций.

\section{Л И ТЕ РА Т У Р А}

Buйдинг X. A. Литолого-минералогический состав и вопросы генезнса терригенных отложений девона Северной Прибалтики. - В кн.: Генезис и классификация осадочных пород. М., 1968, 75-81.

Гидрометеорологический режим озер и водохранилищ СССР. Чудско-Псковское озеро. Л., 1983.

Донные отложения Псковско-Чудского озера. Таллин, 1981.

Пиррус Р., Тасса В. Геология месторождения сапропеля в заливе Вярска. - В кн.: Донные отложения Псковско-Чудского озера. Таллин, 1981, 82-93.

Раукас A. Плейстоценовые отложения Эстонской ССР. Таллин, 1978.

Pаукас A. О вещественном составе донных отложений Псковско-Чудского озера. - В кн.: Донные отложения Псковско-Чудского озера. Таллин, 1981, 23-41.

Раукас А., Ряхни Э. Структурные типы донных отложений Псковско-Чудского озера и особенности их формирования. - В кн.: Донные отложения Псковско-Чудского озера. Таллин, $1981,5-22$.

Ряхни Э., Таваст Э. Рельеф коренных пород в Псковско-Чудской впадине и его роль в распределении донных отложений. - В кн.: Донные отложения Псковско-Чудского озера. Таллин, $1981,127-133$.

Филатова Т. Н. Исследование течений в озерах и водохранилищах. Л., 1972.

Kallejärv, T. Peipsi hoovused. - Eesti Loodus, 1973, nr. 12, 727-731.

Kalm, V. Lämmijärve pōhjasetete lōimis ja levik. - Bioloogia-geograafiateaduskonna UTU töid. Tartu, 1976, 107-111.

Raukas, A. Purdkivimite terasuuruse klassifikatsioon. Tallinn, 1964.

Rõõmusoks, A. Eesti aluspõhja geoloogia. Tallinn, 1983.

Tavast, E. Gravimeetriga talvisel Lämmijärvel. - Eesti Loodus, 1978, nr. 2, 111-112.

$\begin{array}{cc}\text { Институт геологии } & \text { Поступила в редакцию } \\ \text { Академии наук Эстонской ССР } & 12 / \mathrm{V} \quad 1987\end{array}$

Тартуский государственный университет 


\section{LÄMMIJÄRVE PÕHJA- JA RANNASETTED}

Lämmijärv on Peipsi-Pihkva basseinis kōige keerulisema põhjareljeefi ja liigestatuma rannajoonega. Suur on hoovuste mõju. On kirjeldatud lähtekivimite, reljeefi ja hüdrometeoroloogiliste tegurite osa põhjasetete struktuuritüüpide ja mineraalse koostise kujunemisel ning esitatud järve rannatüüpide kaart koos iseloomulike rannasetete lõimiseanalüüsidega.

\section{A. RAUKAS, Elvi TAVAST, V. KALM}

\section{BOTTOM AND COASTAL DEPOSITS OF LAKE LÄMMIJÄRV}

Lämmijärv has the most complicated bottom relief and the most strongly indented coastline of all the lakes situated in the Peipsi-Pihkva basin. The effect of currents is remarkable. The share of initial rocks, relief and hydrometeorological factors in the formation of structural types of bottom deposits (Fig. 3) and mineral composition (Figs $4-6$ ) is discussed and the map of coastal types (Fig. 1) with the data obtained through the grain-size analyses (the Table) presented. 